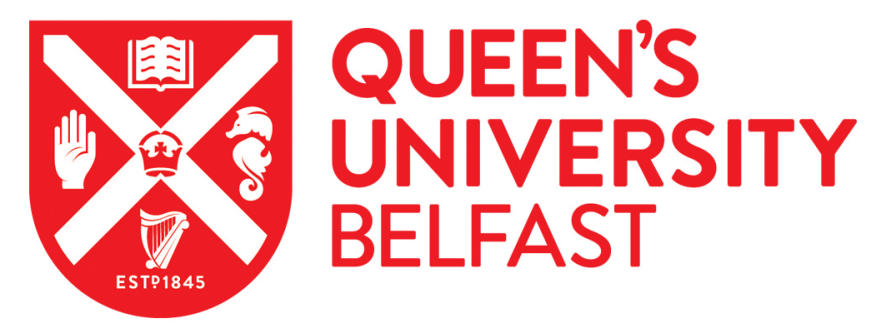

\title{
The Utility of a Psycho-Social Approach for Understanding and Addressing Male Youth Violence: The Interface between Traumatic Experiences and Masculinity
}

Walsh, C. (2019). The Utility of a Psycho-Social Approach for Understanding and Addressing Male Youth

Violence: The Interface between Traumatic Experiences and Masculinity. Journal of Aggression, Maltreatment \& Trauma. https://doi.org/10.1080/10926771.2018.1561572

Published in:

Journal of Aggression, Maltreatment \& Trauma

Document Version:

Peer reviewed version

Queen's University Belfast - Research Portal:

Link to publication record in Queen's University Belfast Research Portal

Publisher rights

(c) 2019 Taylor \& Francis

This work is made available online in accordance with the publisher's policies. Please refer to any applicable terms of use of the publisher.

\section{General rights}

Copyright for the publications made accessible via the Queen's University Belfast Research Portal is retained by the author(s) and / or other copyright owners and it is a condition of accessing these publications that users recognise and abide by the legal requirements associated with these rights.

Take down policy

The Research Portal is Queen's institutional repository that provides access to Queen's research output. Every effort has been made to ensure that content in the Research Portal does not infringe any person's rights, or applicable UK laws. If you discover content in the

Research Portal that you believe breaches copyright or violates any law, please contact openaccess@qub.ac.uk. 


\title{
The Utility of a Psycho-Social Approach for Understanding and Addressing Male Youth Violence: The Interface between Traumatic Experiences andMasculinity
}

\section{Dr Colm Walsh}

School of Social Sciences, Education and Social Work, Queens University Belfast, Belfast, Northern Ireland

\begin{abstract}
Violent offending is a key concern to criminologists, but cur- rent paradigms have not fully explained why some people are violent and others are not. Despite the fact that between $80 \%$ and $98 \%$ of all violent-related crimes are perpetrated by males, few studies have convincingly examined why this is the case. Violence is traumatic and is one of the most commonly experi- enced traumas internationally. Violence is the leading cause of death for young men ages under 24 globally, and in addition to fatalities, there are 10 times more violence-related injuries. In the UK, $78 \%$ of perpetrators of violent crime are male, and the vast majority of victims are male. Two things appear clear: violence is pervasive and is the most common trauma experi- enced by boys and young men. This article seeks to highlight the need for both a trauma-informed approach as well as a gender-conscious approach in the discourse around violence prevention research, policy, and practice.
\end{abstract}

The Utility of a Psycho-Social Approach for Understanding and Addressing Male Youth Violence: The Interface between Traumatic Experiences and Masculinity

The long-term relationship between Adverse Childhood Experiences (ACEs) such as exposure to violence in the home and in the community, healthharming behaviors, poor physical and mental health outcomes, and ultimately, early mortality was first documented by Felitti et al. (1998) in their seminal study with more 8,000 people in the United States. However, it is clear that not all people experience the same types of adversity (Grasso, Dierkhishing, Branson, Ford, \& Lee, 2015) and even when they do, the behavioral outcomes vary considerably (Cecila, Viding, Fearon, Glaser, \& McCrory, 2017). Exposure to extra-familial violence and subsequent violent offending appears to be particularly gendered (McNaughton- Ryes, Foshee, Chen, \& Ennett, 2018; Vaswani, 2018). Since the original investigation, later epidemiological studies, such as those in the UK have confirmed thedeleterious and doseresponse effects of adversity during childhood on later offending behaviors, with those exposed to multiple adversities and violent trauma, significantly more likely to engage in violence (Bellis, Hughes, Leckenby, Perkins, \& Lowey, 2014).

Violence may be a significant social problem with both social and economic costs (Walsh, 2018) but however pervasive (Krauss, 2006), it is not a new phenomenon. Records suggest that observers were keen to understand the mechanics of intentional aggressive behavior as far back as the time of the 
Ancient Greeks, 400 BCE (Veenstra, Bushman, \& Koole, 2018). In the twentyfirst Century, its prevalence, its causes, and its cures continue to be of critical interest to criminologists. And yet, despite evidence of increasingly high levels of exposure to violent trauma and high levels of violent offending (Home Office, 2018), studies have struggled to engage with and explain both its causes and, in turn, its potential cures (Englander, 2003; Gadd \& Jefferson, 2007).

The purpose of this article is to outline how conceptualizing both the perpetration and victimization of violence through a gender and trauma lens could help inform the investigation as well as prevention of violence.

First, the article will situate the investigation of violence within contemporary criminological research and argue that the focus of research to date has focused almost exclusively on either systemic or individual risk factors, largely ignoring the interface between both the individual and their environment. Second, the article will outline the extent to which violence continues to be a pervasive social concern. Thereafter, it will be argued that combining a traumainformed approach along with a gender-conscious approach could facilitate a greater understanding of the drivers of violent offending and inform a new generation of violence prevention strategies. Given the dearth of data from a European, UK, and Ireland context, where available, the article will draw on evidence from these regions.

\section{Researching violence}

Although pervasive, the causal pathways into and out of violent offending remain elusive. One of the reasons has been the limited number of highquality longitudinal studies capturing intersections between predictors of aggression and violent outcomes (Hawkins et al., 2000; Farrington, Gaffney, $\&$ Ttofi, 2017). Another factor has been the dearth of European- and UKbased empirical studies over recent decades, with much of the academic literature coming from studies implemented in the United States (Filton, Rongqin, \& Fazel, 2018; Malvaso et al., 2018). Of those, many were influenced by significant scientific advances throughout the twentieth century leading to increasing empirical interest in risk factors associated with relatively fixed personal characteristics such as gender (Messerschmidt, 1993), genetics, and hormones (particularly testosterone) (Carre \& Archer, 2018) 
and personality traits (particularly callous and empathetic traits) (Joliffe \& Farrington, 2004). Other reviews however have found that rather than deterministic, these bio-psychological variables become more important in the context of the environment they are exposed to (van der Merwe \& Dawes, 2009). For instance, despite some evidence that testosterone levels predicted levels of aggression in both animals (Beeman, 1947) as well as in humans (Halpern, Udry, Campbell, \& Suchindran, 1994), later studies found mixed results with the relationship being correlational rather than causal (Archer, Graham-Kevan, \& Davies, 2005). Rather than explaining behavior, testosterone levels appeared to rise and fall as a result of both pro-social and anti-social stimuli (Carre \& Archer, 2018). As a result, a significant number of studies on the criminogenic effects of environmental and social systems on offending individuals have been undertaken. During childhood, negative peer relationships (Hawkins et al., 2000), poor social ties, and bullying, as well as exposure to maltreatment (Derzon, 2010) and community violence (Walsh, 2018) have shown to be stronger predictors of violence than individual traits. Another important phase in the evolution of criminological research was the emergence of what is commonly referred to as critical or radical criminology in the 1960s and 1970s (Taylor, Walton, \& Young, 1973). Investigations into the determinants of violent crime focused largely on issues of social justice (poverty, deprivation, education, and rights) as well as problematic structural relations between groups in society The impact in many European countries and in particular UK academic circles was a shift away from understanding the individual in the context of violent offending and the cognitive processes associated with propensity toward aggression and violence. This prevented many key questions from being explored including, why do some people commit violent crime and others do not (Gadd \& Jefferson, 2007; Jones, 2012)?

The reasons were understandable. Following the Second World War, as criminology became instituted as a formal discipline, Lombrosian accounts of crime focused on the deterministic nature of offenders and the heritability of propensities toward crime, but in the context of the eugenics movements and Nazi propaganda, criminology rightly pushed against these absurdities and the result was an almost exclusive focus on sociological explanations of violent offending (Garland, 2002). In later years, the demonizing of youth sub cultures and reference to folk devils, bound with a moral panic (Cohen, 2011), added further fuel to this resistance. Individual accounts of violent crime and the criminogenic effects of subjective experiences were muted. The outcome of a distancing from early and crude psychodynamic understandings of crime was that anything that attended to the individual offender became characterized as Lombrosian (Gadd \& Jefferson, 2007). This was deeply flawed and conflated the object of interest (the individual) with the theory or paradigm that helped the discipline to understand the behavior (the science of causes). Radical criminology lost some of the tools to comprehensively and collectively understand and 
engage with emerging evidence. This was during a time when it was becoming increasingly clear that those who engage with the justice system often experience significant adversity (Ramon, 1989) resulting in emotional and psychological harm. Despite strongly advocating the critical paradigm, Taylor, Walton, and Young (2013) described three levels at which violent crime must be understood and responded to: 1 . The act; 2 . The immediate origins; and 3 . The wider origins. This simple framework for a complex problem such as violent crime implied the need to understand crime, its causes, and its cures from at least three perspectives. Administrative perspectives, with its focus on systems and processes, facilitate our understanding of the prevalence of violent crime; psychological perspectives enable us to understand the proximal drivers associated with violent behavior, and sociological perspectives enable us to understand the broader systemic causes of violent crime and distal influences. For the most part, a combination of all three in empirical criminological research is rare.

\section{Violence: The problem}

Violence is traumatic and is one of the most commonly experienced traumas globally. It is a persistent and significant social challenge (Englander, 2003). Global health data suggest that it is the leading cause of death for all young men under the age of 24 and in addition to fatalities, there are 10 times more violence-related injuries (Mikhail \& Nemeth, 2015; UNICEF, 2017). Up to 500 young people are dying each day as a result of violence (Baxendale, Cross, \& Johnston, 2012). In addition to fatalities, there are over 10 times more non-fatal altercations (Mikhail \& Nemeth, 2015). Violence is also a costly problem. Excluding armed conflict, violence costs almost $£ 30 \mathrm{bn}$ annually with implications for the individual, families, the community, and wider society (Bellis, Hughes, Perkins, \& Bennett, 2012).

Both during peace as well as conflict, violence is highly gendered. In a South African longitudinal population study, Richter, Matthews, Kagura, and Nonterah (2018) found that only $1 \%$ of the cohort had not been exposed to violence; boys were at greater risk of some forms of violence; and an escalation of violence was experienced for young people over the age 14. In the UK, official figures suggest that $78 \%$ of perpetrators of violent crime are male (ONS, 2018), and in a UK-based cross-sectional study, Jackson, Brown, and Stephen (2016) found that $98 \%$ of male victims in a UK study were attacked by other males. In contexts defined by conflict such as in Northern Ireland (NI), young men appear to be more likely to be seriously or fatally hurt as well as more likely to be convicted of conflict-related crime (Fay, Morrissey, \& Smith, 1998). Despite some figures suggesting that UK incidents of violence have steadily reduced since the late 1990s, hospital data suggest a steady rise in forms of more serious violence since 2014 and 2015 (ONS,2018). In NI, the Department of Health sets health policy and five regional health Trusts are responsible for delivery. Neither the department nor the Trusts in NI routinely 
collect or report on presentations to Accident and Emergency (A \& E), obscuring any potential evidence around the link between victimization and perpetration of violence. Whilst there is a need for a more strategic approach to understanding violence at a regional level, comparative data from England and Wales indicate a rise in presentations to $\mathrm{A} \& \mathrm{E}$ as a result of violent injury.

In addition to health-related data, police statistics reveal that some forms of violence have significantly increased. Figures for the period 2012-2017 show that knife crime rose by over $30 \%$ and gun crime by just under 30\% (Home Office, 2018). Latest police figures for England illustrate that there were 1.2 million incidents of violence during 2017, the first time that the figure exceeded 1 million (ONS, 2018). Violent crimes such as homicides, knife crime, and gun crime have risen considerably since 2014. Both empirical (McNaughton et al., 2018) and criminal justice data suggest that in addition to being more likely to be the victim of serious interpersonal violence, young men are also more likely to be the perpetrator (Maschi \& Bradley, 2008).

In NI, violence against the person currently represents around one third of all crimes recorded, compared with less than 20\% of all crimes in 1998-1999. Between, 1999 and 2016, the figure had almost doubled (PSNI, 2018). Whilst the overall crime figures for NI are comparably lower than that in England and Wales, a population-based survey found that the NI public were significantly more concerned about violent crime than those in England and Wales (NISRA, 2018). Internationally, little is understood about young men's experiences of crime and violence, particularly as a perpetrator. Research exploring the causes of men's violence and challenges as a result of exposure to violent crime largely focus on men's perpetration of violence against women (Dagirmanjian et al., 2016). Systematic reviews and meta-analysis that have been undertaken to date have tended to focus on intervention effectiveness rather than explanatory variables. Additionally, these reviews have focused on systemic risk factors for engagement in violence and crime (Derzon, 2010; Egan, 2009; Johnson, 2009; Malvaso, Delfabro, \& Day, 2016; Tfofi, Farrington, \& Losel, 2012), largely excluding the complex role of young men as both victim and perpetrator (Harland \& McCready, 2015).

Understanding the drivers and then prevalence of serious male youth violence is important. If the drivers are understood, and defined clearly, responses are potentially more effective. If data are collected in an evidence- based way and then shared, critical patterns which help to illuminate correlational and causal factors will emerge.

Several high-level policy iterations have responded to what is often coined as social crisis. The latest iteration in the UK is the "Serious Youth Violence Strategy" (Home Office, 2018). The Strategy points to overwhelming 
evidence that 'males commit the majority of serious violence' (Home Office, 2018 , p. 39) and yet gender is not referenced anywhere as either a driver or a risk factor (Walsh, 2018). Indeed, there are less than 20 individual refer- ences to boys or men throughout the 111-page document. As a result, responses potentially miss some fundamental realities about the perpetration of violent offending. Despite being a constant predictor of aggressive atti- tudes, gender is an area of young men's lives that has been consistently overlooked in violence research, policy, and practice (Sundaram, 2013). Indeed comparable figures from across over 50 developed and developing countries found that over 1.2 million young people died in 2015. The leading causes of death for girls that during adolescence (10-19) were respiratory infections and later, maternal complications. For boys and young men ages $0-19$, risky and violent behaviors were the top two causes of fatality globally (UNICEF, 2017). Two things appear clear, violence is pervasive, and is the most commonly experienced trauma by boys and young men (Farrell \& Zimmermann, 2017; Jackson et al., 2016; ONS, 2018; Winstok \& Weinberg, 2018). How can our contemporary understandings of the cognitive responses following trauma exposure combined with our understandings of the social construction of gender help to inform a modern violence prevention research, policy, and practice framework?

\section{The role of trauma}

Traumatic events can be described as those incidents or series of incidents that are experienced by an individual as physically or emotionally harmful or life threatening (Abate, Marshall, Sharp, \& Venta, 2017). Trauma types vary and can include physical abuse, sexual abuse, maltreatment, violence, as well as incidents vicariously experienced. Trauma can be experienced singularly or in multiples (Buckingham, 2016). Type 1 trauma relate to single incidents and Type 2, often referred to as complex trauma, are incidents that are experienced in multiple ways and multiple times (NHS Scotland, 2017). Epidemiological research suggests that globally, a significant proportion of young people are exposed to events such as conflict, physical abuse, sexual violence, natural disasters, and disease (Morina, Koerssen, \& Pollet, 2016). Some suggest that trauma exposure during childhood is so common that it is normative (Greenwald, 2002). Other studies have found that despite this high prevalence which vacillates depending on the study and its design, across the general population, most people are resilient and do not suffer from any long- term or persistent psycho-social problems (Cecila et al., 2017; Greenwald, 2002; Horn, Charney, \& Feder, 2016; Trickey, Siddaway, Meiser-Stedman, Serpell, \& Field, 2010). But for some, symptoms can be challenging and sometimes damaging. Symptoms of trauma exposure include nightmares, flashbacks, the inability to cope, hyper-arousal, misinterpretation of cues, 
overreaction, self-harm, fight or flight, and disassociation (Morris, Salvovskis, Adams, Lister, \& Meiser-Stedman 2015).

Trauma exposures may lead to the development of psycho-social disorders such as PTSD, anxiety, and/or depression (Buckingham, 2016; Foa \& Rothbaum, 1998; Nothling et al, 2016) and often with a high degree of comorbidity (Contractor et al., 2014; Ying, Wu, \& Lin, 2012). For those who experience negative sequelae, studies have found that age, gender (Ehlers \& Clarke, 2000), and peri-trauma factors such as secure and stable social supports (Trickey et al., 2010) greatly influence the outcomes experienced following adversity. For example, the timing of when a young person experiences an ACE determines that type of trauma that ACE might be. Infants are more likely to experience neglect and within the family home (Briggs, Carter, \& Ford, 2012); during late childhood, the risk of a wider range of maltreatment, including physical and sexual assault is higher (Finkelhor, Ormrod, Turner, \& Hamby, 2005); and during adolescence, girls are more likely to experience sexual assault (Raissian, Dierkhising, Geiger, \& Schelbe, 2014) whilst boys are more likely to experience interper- sonal violence in the community.

In relation to gender, women have been found to be at higher risk of clinical disorders such as PTSD, anxiety, and depression and men have been found to be at greater risk of behavioral difficulties, cognitive misinterpretations of risk, and increased aggression (Winstok \& Weinberg, 2018). Indeed, some studies have found that there have been stronger associations between the type of trauma experienced (van der Put, Lanctot, de Ruiter, \& van Vugt, 2015) and offending outcomes whilst others have found that rather than the type of trauma, the dose-effect of cumulative, and chronic trauma exposure is more high correlated to offending behaviors (Lauterbach \& Armour, 2016). In essence, higher trauma load is associated with increased risk of mental health issues and negative behavioral responses, including offending behavior (Nothling, Suliman, Martin, Simmons, \& Seedat, 2016; Turner \&Llotyd, 1995).

Across national boundaries, cultures, and social contexts, the fact that many of the prison population have experienced trauma is irrefutable (Buckingham, 2016; Komarovskaya, Booker-Loper, Warren, \& Jackson, 2011). There is now significant evidence that those who engage in violent offending have been victims themselves (Dierkhising et al., 2013; Falshaw Browne, \& Hollin, 1996). Although estimations of the prevalence of trauma for all children in the USA are relatively high at $34 \%$, between $75 \%$ and $93 \%$ of children entering the juvenile justice system reports that they have experienced at least one traumatic event (Branson \& Baetz, 2017). Several international studies including one in the USA (Carlson \& Schafer, 2010) and one in South Africa (Richter et al., 2018) found that across the prison population, the majority of perpetrators had been victims of childhood trauma including witness to or victim of interpersonal violence. In a nationally representative US sample, $99 \%$ of perpetrators of violence had reported being victims of violence 
themselves (Maschi \& Bradley, 2008) and other studies have found prevalence rates of between $60 \%$ and $90 \%$ of exposure to violence amongst young offenders (Aebi et al., 2017).

There is growing evidence that these traumatic experiences are not only correlational but causal factors associated with violent offending (Kerig \& Becker, 2010). Messina and Grella (2006) found that there was a cumulative effective of trauma exposure and, in particular, early trauma experiences were highly correlated with early-onset offending.

In an European population-based survey of over 6,000 ninth graders in Switzerland, it was found that those who experienced trauma were significantly more likely to engage in violence and males, particularly those with high levels of dysphoric arousal and low levels of anxiety, were particularly at risk of perpetrating violence (Aebi et al., 2017). Although around $85 \%$ of the general population will recover following trauma, this is greatly reduced in the justice population with estimates as low as $20 \%$ depending on the nature of the trauma and dose-response effects (Buckingham, 2016). Hasley (2018) describes this as internalized pain manifesting as externalized violence.

The first to critically appraise the connection was Fairbairn (1943) who referred to the "return of bad objects." For many young people whoexperience trauma, feelings and memories are repressed. When a release or response is unavoidable, those feelings are externalized as aggression toward self or others (Hasley, 2018). The idea being that repression of hurt and psychological pain returns in destructive and harmful ways. This idea was elaborated upon further by Widom (1989) who may be the first scholar to specifically study the impact of trauma, and specifically violence on offending trajectories. The criminogenic effects of adversity are well established, but criminological research has failed to engage in discourse around under what circumstances, through what developmental processes, and within which social context does trauma influence violent offending. Why do some young people engage in violence following trauma exposure and others do not? And particularly, why is violent offending significantly differentiated by gender?

In recent years, there have been many innovations in trauma-focused treatment. Unfortunately, the youth justice system has not caught up with the contemporary understanding of trauma's impact on offending and the latest evidence-based practices to address trauma. Specifically, there is no screening for trauma and youth justice approaches often include counter- productive responses to youth offending, such as removal from the home, and the delivery of treatment that is general rather than trauma-specific, and the over-use of detention (Buckingham, 2016). For too long, the concept of and response to trauma has been perceived as a clinical issue, only under- stood and better responded to in the context of psychological and psychiatric services. But overwhelming evidence that a large proportion of the criminal justice 
population have been impacted by trauma is facilitating greater discourse within criminology.

Interviewing prisoners in Australia, Hasley (2018) found that the majority of crimes committed by those interviewed could be considered understood in the context of trauma. Specifically, aggressive behaviors in the study represented the externalization of psychological pain and a systemic failure to both recognize the prevalence of trauma through effective screening combined with a failure to invest in treatments which reduce the impact of trauma. The cumulative effect was to greatly increase the risk of victims' own offending behavior. The criminogenic effects of trauma are clear (Farrell \& Zimmermann, 2017) and yet little focus is placed on the role of childhood trauma within criminology. This has slowed down criminological investigation and, as a result, the socio-emotional pathways that link trauma to offending for some young people and not to others are not well understood (Maschi \& Bradley, 2008). To date, only a few studies have attempted to examine the relationship between emotional and cognitive processes associated with violent offending and the majority of these have focused on US studies (Dierkhising et al., 2013). Piquero, Jennings, \& Barnes, (2012) found 37 studies related to youth violence through analysis of aggregated data found a significant associa- tion between victimization and offending. Two more recent systemic reviews (Filton et al., 2018; Malvaso, Delfabbro, \& Day, 2018) exploring the relation- ship between maltreatment and violent offending for instance found relatively few studies in this area. In the former, only 18 high-quality studies were available between 1989 and 2016 (Filton et al., 2018), and in both studies the majority were conducted in the USA (78\% \& 94\%). Filton et al. (2018) established that whilst some forms of trauma are stronger predictors of violence, they only modestly predict perpetration.

So, whilst trauma is important, it is not the only factor at play. Commonly cited theories that have helped to contextualize violent offending include General Strain Theory (GST) (Agnew, 2002). From this perspective, there are three types of strain experienced: that directly experienced; that anticipated but not yet experienced; and that vicariously experienced (Farrell \& Zimmermann, 2017). But what GST cannot wholly account for is the heterogeneity between victims and in particularly why young men are more likely than young women to engage in violent offending following violent victimization. In fact, in their population-based longitudinal study, young men were twice as likely to engage in violent behavior and those exposed to two or more types of violence were five times as likely (Farrell \& Zimmermann, 2017). It appears that from the perspective of the perpetrator, all crime, including the most bizarre, makes sense and is influenced by the social processes around the structures in which they live and the cognitions that enable them to understand and navigate the world (Gadd \& Jefferson, 2007). For instance, early trauma experiences change developmental processes from one of the learnings to one of the survivals (Ford \& Curtois, 2009). Because of the interplay 
between individual experiences, cognitive processes, violence, and the world around the individual, it is essential to deal with the ecology of trauma (including the toxic social ecology of many custodial environments) (Hasley, 2018).

\section{The role of gender: Masculinity}

Trauma exposure may create aggressive pathways through hyperarousal, hypervigilance, and inappropriate hostile reactions, but as we've seen throughout this article. The extent to which these mentalizing responses to trauma become actualized in behavior is significantly differentiated by gender. In many feminist accounts of the role of masculinity in the perpetration of violence, the act is seen as a manifestation of power rather than a defence against powerlessness (Gadd \& Jefferson, 2007). In the context of trauma experienced, young men lose the power which they have been socially constructed to attain. Additionally, the hurt and loss that they experience is concealed for fear of being unmasked, being exposed, and being perceived as anti-masculine (or feminine).

It's therefore fundamentally wrong to analyze the perpetration of youth violence in the context of a violent incident or even the traumatic impact. If we are to move prevention forward, we need to frame violence in the context of young men's lives (Hamby, Taylor, \& Jones, 2018) and these of course are experienced both socially and psychologically. Gender, and in particular masculinity, are the greatest social realities for young men (Harland \& McCready, 2015). In this sense, both psychological accounts of how young men understand their worlds and how their experiences shared their attitudes and beliefs as well as sociological explanations around how gender is constructed and played out are of critical importance to understanding young men's responses to trauma and the perpetration of violence amongst young men (Winstok \& Weinberg, 2018).

Popular strains of psychoanalytic thought such as Object Relations can make relevant contributions to our understanding of the interaction between the psychological and social in relation to masculinity and violence. This approach provides an understanding for how internal worlds interact with and are interacted upon by the external world. As we have seen, cumulative empirical data demonstrate significance of individual histories on offending trajectories. As such, the individual cannot simply be discounted. But neither can the social influences around them. Several gender theories are useful in the context of violence research. Connell's (1995) illustration of hegemonic masculinity suggests a hierarchy of masculine norms together with normative masculine behaviors influence young men's perceptions of their roles, responsibilities, and acceptable behaviors.

The concept of "hegemonic masculinity" appeared in the 1980s as empirical research with boys and men grew (Carrigan, Connell, \& Lee, 1985). Connell developed the ideas further to explain the dominance of men over 
women and also some men over other subordinate groups of men. Exemplary masculinities are constructed, which, often, do not correspond closely to the lives of the majority of men, but, still, they express the ideals and provide models of relations with women and other men (Connell, 2002). Another useful framework is Gender Motivation Theory (GMT) which posits that there are fundamentally two basic social expectations, and consequently two basic gender motives namely, "Status Enhancement" (i.e., increasing personal and social status) and "Risk Reduction" (i.e., increasing personal safety) with men more likely to be concerned with the former and women more likely to be affected by the latter (Winstok \& Weinberg, 2018).

Both of these gender theories why young men who accept more traditional forms of masculinity are more aggressive in their social responses (Amato, 2012; Reardon \& Govender, 2013). Indeed, a recent study of 1,000 Australian young men by the Queensland University of Technology found this group were seven times more likely than other young men to engage in violence (Irvine, Livingstone, \& Flood, 2018). In striving to achieve traditional or normative masculinity and enhance their status, young men can refute any thoughts/feeling or behaviors perceived to be feminine and actively police other young men's behaviors also (Harland \& McCready, 2014). Young men particularly from deprived areas are trapped in a social context which encourages them to attain traditional masculine traits and punish those who do not (McAlister, Scraton, \& Haydon, 2014). Fonaghy, Target, Gergely, Allen, and Bateman (2003) argued that being able to understand, reflect upon, and process emotions following social stimuli is critical for the reductions in hostility and aggression all of which are commonly perceived as feminine characteristics and skills which boys resist as they develop. Without this capacity however, individuals respond rather than think to that social stimuli and often the context is misinterpreted (Jones, 2012).

Hyper masculine beliefs appear to enable males to justify violence on the grounds of demonstrating their identity, attaining status in a group, and/or protect themselves from a perceived threat. Hegemonic masculinity creates rules by which young men set behavioral expectations for themselves (Amato, 2012; Sundaram, 2013). From an early age, boys are conditioned to behave and act a certain way that is different to girls and socialized into expectations of behavior (Crooks et al., 2007). Across cultures, masculine identities define what it means to be male and the parameters of behavior which are acceptable. Young men, who are more likely to be exposed to interpersonal non-sexual violence, come to learn that violence is not only appropriate behavioral responses but necessary (Akers, Krohn, Lanza- Kaduce, \& Radosevich, 1979). Aggression as the legitimate form of expres- sion is reinforced as boys develop. This can be particularly problematic when young men face challenging and traumatic events. Hegemonic masculinity 
and GMT may help to explain why boys who have been exposed to trauma have a higher risk of acting violently (Aebi et al., 2017).

Despite this, the potential association between masculinity and trauma has been under evaluated and the mechanisms by which trauma affects behavior amongst young men not well understood. Matjasko et al. (2012) in their metareview of 52 violence prevention studies found that few studies explored individual characteristics which increased the risk of violence. Genderconscious and Trauma-informed approaches which take into account masculine identities have the potential to prevent serious violence, reduce recidivism, and address chronic community violence.

\section{Next steps}

Over recent decades, there has been a lack of investment in understanding the nature of male youth violence with the few high-quality empirical studies primarily coming from the United States. Given the scale of the problem, the human and economic costs, culturally and contextually relevant studies are needed to examine the behavioral outcomes and root causes.

Research and administrative data which facilitate more accurate and timely monitoring of victimization and perpetration of violence across health and justice systems would greatly advance empirical investigation. These data should be available. For instance, we know that in many cases, violent offending by its nature results in at least two contacts with public authorities. The victim is often in receipt of medical care and this is documented at emergency departments, and these data are held by health departments. The perpetrator, if charged, is often dealt with via the courts and these data are held by justice departments. In NI, these figures are collected by the Department for Justice but not routinely report on. The data in relation to ED presentations are neither collected nor reported on. Neither department appears to align their data with the other. Therefore, we have only but a partial picture. Data are underused and do not currently lend itself to understand correlational and casual factors associated with male youth violence. Moving forward, a more strategic approach could be taken at policy level to report on data that are collected and to facilitate analysis of that data in a more coherent and wellintegrated manner.

Studies on trauma and violence point to the deleterious effects of childhood trauma and specifically to the likelihood of criminality for those unable to connect to the right kinds of support (Hasley, 2018). The concept of trauma-informed service systems was first introduced into the literature over 15 years ago by Harris and Fallot (2001) but has had little impact on either policy or practice. This may be partly because there is no consistent or coherent definition of what trauma-informed justice is or how it could be 
implemented (Branson \& Baetz, 2017). Four consistent elements however include: (1) accurately screening for trauma, (2) incorporating a contemporary understanding of trauma and its effects into legally significant transactions, particularly into its assessment of culpability, (3) implementing evidence-based treatments, (4) and integrating trauma responses into disposals handed down by courts following conviction (Buckingham, 2016). Despite the overwhelming evidence that trauma has an adverse impact on behaviors, the good news is that when trauma is identified and treated with appropriate, trauma-specific methods, the impact can be mitigated, and outcomes can be positive. By recognizing that the underlying causes of violent offending may be explained by this trauma (Buckingham, 2016) and investing in approaches which both address the impact of adversity, trauma informed justice becomes trauma responsive justice. Moving forward, more research emphasis could be placed on understanding how frontline staff can more effectively and actively under- stand the role that trauma plays in the lives of those who engage in violent offending and respond in a way that is constructive and evidence based.

But we have seen that trauma exposure is by itself not sufficient to result in violent behavior. Other factors must be present, and the argument presented here is that gender constructions and in particular masculinity moderates the extent to which trauma is then followed by violent offending. This is an underevaluated area of research, and more high-quality studies are needed to test this hypothesis.

\section{Conclusion}

Violent offending is a key concern to criminologists, but current paradigms have not fully explained why some people are violent and others are not. Despite the fact that between $80 \%$ and $98 \%$ of all violent-related crimes are perpetrated by males, few studies have sought to examine why this is the case (Ardino, 2012; Brown \& Burton, 2010) and any evidence which does point to the relationship between gender, trauma, and violent offending has had little impact on criminological research or indeed crime prevention as a social policy (Malvaso et al., 2018). Trauma-informed theories provide some empirical basis, but these too are not conclusive. For instance, trauma research shows that there is significant heterogeneity between victims and outcomes. What we do know however is that the type of trauma that young men are more likely to be exposed to is violent and the outcomes are more likely to be aggressive. One possibility is that masculinity moderates this relationship and the greater the acceptance of traditional masculine norms, the higher the propensity toward violence in response to traumatic events. Research needs to be undertaken to understand the relationship between young men's exposure to traumatic events and to explore and explain the transition between gender constructions and exaggerated masculinities (Goodey, 1997). Employing a psycho-social approaches to this research could provide a valuable framework. In this way, we manage "to hang on to the social 
and psychic dimensions of experience: embracing both and privileging none" (Gadd \& Jefferson, 2007, p. 184). Additionally, given young men's unique position in that they are more likely to experience violent crime both as victims and perpetrators, few studies have sought to explore the therapeutic needs of young people exposed to various forms of crime (Finkelhor et al., 2009). In order to understand exposure to crime and perceptions of crime, it is therefore important to identify those who need additional supports and prevent further victimization.

As Gadd and Jefferson (2007) suggest, in understanding violence we are required to

...do so using understandings of psychic life and of the social world - and their interrelationship - that are applicable to all: pacifist church-goer as well as multiple murderer. This should humanize the criminal...those we do not understand we can more readily demonize, thus enabling "folk 4 devils and moral panics" to continue to figure prominently in the contemporary politics of law and order. (p. 2).

Bridging two disparate perspectives on violence ensures that alongside social and cultural perspectives of violence, the individual is not lost (Gadd \& Jefferson, 2007). To truly engage with the reality of violent crime, criminology must not only attend to the influence and impact of structures, but to the individual, their subjective experience, and cognitive responses to social stimuli. The purpose of this psycho-social approach is not simply to ensure that different perspectives are heard, but to ensure that the individual subjective world is incorporated into social and cultural understandings of the root causes of violent offending (Jones, 2012).

To advance our understanding of the nature of youth violence, its causes, and possibly approaches to reducing it, policies and practices should not only be trauma informed but also, and critically, gender conscious.

\section{References}

Abate, A., Marshall, K., Sharp, C., \& Venta, A. (2017). Trauma and aggression: Investigating the mediating role of mentalizing in female and male inpatient adolescents. Child Psychiatry and Human Development, 48, 881-890. doi:10.1007/s10578-017-0711-6 
Aebi, M., Mohler-Kuo, M., Barra, S., Schnyder, U., Maier, T., \& Landolt, M. A. (2017). Post traumatic stress and youth violence perpetration: A population based cross sectional study. European Psychiatry, 40, 88-95. doi:10.1016/j.eurpsy.2016.08.007

Agnew, R. (2002). Experienced, vicarious and anticipated strain: An exploratory study on physical victimisation and delinquency. Justice Quarterly, 19, 267-294. doi:10.1080/ 07418820200095371

Akers, R. L., Krohn, M. D., Lanza-Kaduce, L., \& Radosevich, M. (1979). Social learning and deviant behaviour: A specific test of a general theory. American Sociological Review, 44(4), $636-655$.

Amato, F. (2012). The relationship of violence to gender role conflict and conformity to masculine norms in a forensic sample. The Journal of Men's Studies, 20, 187-208.

Archer, J., Graham-Kevan, N., \& Davies, M. (2005). Testosterone and aggression: A reanalysis of a book, Starzyk and Quinsey's (2001) study. Aggression and Violent Behaviour, 10, 241261. doi:10.1016/j.avb.2004.01.001

Ardino, V. (2012). Offending behaviour: The role of trauma and PTSD. European Journal of Psychotraumatology, 3. doi.org/10.3402/ejpt.v3i0.18968

Baxendale, S., Cross, D., \& Johnston, R. (2012). A review of the evidence on the relationship between gender and adolescents' involvement in violent behaviour. Aggression and Violent Behavior, 17, 297-310. doi:10.1016/j.avb.2012.03.002

Beeman, A. E. (1947). The effect of male hormone on aggressive behaviour in male mice. Physiologica Zoologist, 20, 373-405.

Bellis, M., Hughes, K., Leckenby, N., Perkins, C., \& Lowey, H. (2014). National household survey of adverse childhood experience and their relationship with resilience to health-harming behaviours in England. BMC Medicine, 12(72). doi:10.1186/s12916-014-0141-2

Bellis, M., Hughes, K., Perkins, C., \& Bennett, A. (2012). Protecting people, promoting health. Liverpool, England: NHS.

Branson, C., Baetz, C., Horwitz, S., \& Hongwood, K. (2017). Trauma-informed juvenile justice systems: A systematic review of definitions and core components. Psychological Trauma: Theory, Research, Practice, and Policy, 9(6). doi:10.1037/tra0000255

Briggs-Gowan, M. J., Carter, A. S., \& Ford, J. D. (2012). Parsing the effects violence exposure in early childhood: Modelling developmental pathways. Journal of Paediatric Psychology, 37, 11-22. doi:10.1093/jpepsy/jsr063

Brown, A., \& Burton, D. (2010). Exploring the overlap in male juvenile sexual offending and general delinquency: Trauma, alcohol use and masculine beliefs. Journal Of Child Sexual Abuse, 19, 450-468. doi:10.1080/10538712.2010.495044

Buckingham, S. (2016). Trauma informed juvenile justice. American Crime L, 53(Rev), 641. Carlson, B., \& Shafer, M. (2010). Traumatic histories and stressful life events of incarcerated parents: Childhood and adult trauma histories. The Prison Journal, 90, 475-493. doi: $10.1177 / 0032885510382224$

Carre, J., \& Archer, J. (2018). Testosterone and human behaviour: The role of individual and contextual variables. Current Opinion in Psychology, 19, 149-153. doi:10.1016/j. copsyc.2017.03.021

Carrigan, T., Connell, R., \& Lee, J. (1985). Toward a new sociology of masculinity. Theory and Society, 14(5), 551-604. doi:10.1007/BF00160017

Cecila, C., Viding, E., Fearon, P., Glaser, D., \& McCrory, E. (2017). Disentangling the mental health impact of childhood abuse and neglect. Child Abuse and Neglect, 63, 106-119. doi:10.1016/j.chiabu.2016.11.024

Cohen, S. (2011). Folk devils and moral panics. London, UK: Routledge.

Connell, R. W. (1995). Masculinities. Cambridge, UK: Policy Press. 
Connell, R. W. (2002). On hegemonic masculinity and violence: Response to Jefferson and Hall. Theoretical Criminology, 6(1), 89-99. doi:10.1177/136248060200600104

Contractor, A., Durham, T., Brennan, J., Armour, C., Wutrick, H., Frueh, C., \& Elhai, J. (2014). DSM-5 PTSD's symptom dimensions and relations with major depression's symp- tom dimensions in a primary care sample. Psychiatry Research, 215, 146-153. doi:10.1016/j. psychres.2013.10.015

Crooks, C. (2007). Engaging men and boys in preventing violence against women. Violence against Women, 13(3), 217-239. doi:10.1177/1077801206297336

Dagirmanjian, B. F., Mahalik, J. R., Boland, J., Colbow, C., Dunn, J., Pomarico, A., \& Rappaport, D. (2016). How do men construct men's violence? Journal of Interpersonal Violence, $32,15$.

Derzon, J. (2010). The correspondence of family features with problem, aggressive, criminal, and violent behavior: A meta-analysis. Journal of Experimental Criminology, 6(3), 263-292. doi:10.1007/s11292-010-9098-0

Dierkhising, C., Ko, S., Woods-Jaeger, B., Briggs, E., Lee, R., \& Pynoos, R. (2013). Trauma histories among justice involved youth: Findings from the National Child Traumatic Stress Network. European Journal of Psychotraumatology, 4, 1. doi:10.3402/ejpt.v4i0.20274

Egan, S. J. (Ed.). (2009). Posttraumatic stress disorder (PTSD): Causes, symptoms and treatment Hauppauge. New York, NY: Nova Science Johnson.

Ehlers, A., \& Clark, D. M. (2000). A cognitive model of posttraumatic stress disorder. Behaviour Research and Therapy, 38, 319-345.

Englander, E. (2003). Understanding violence (2nd ed.). NJ: Lawrence Erlbaum Associates Publishers.

Fairbairn, W. (1943). The repression and return of bad objects (with special reference to the 'war neuroses'). British Journal of Medical Psychology,32179(3), －341. doi:10.1111/j.20448341.1943.tb00328.x

Falshaw, L., Browne, K. D., \& Hollin, C. R. (1996). Victim to offender: A review. Aggression and Violent Behavior, 1(4), 389-404. doi:10.1016/S1359-1789(96)00005-5

Farrell, C., \& Zimmermann, G. (2017). does offending intensify as exposure to violence aggregates? Reconsidering the effects of repeat victimisation, types of exposure to violence and poly-victimisation on property crime, violent offending and substance use. Journal of Criminal Justice, 3, 25-33.

Farrington, D., Gaffney, H., \& Ttofi, M. (2017). Systematic reviews of explanatory risk factors of violence, offending and delinquency. Aggression and Violent Behavior, 33, 24-36. doi:10.1016/j.avb.2016.11.004

Fay, M., Morrissey, M., \& Smyth, M. T. (1998). Mapping troubles-related deaths in Northern Ireland 1969-1998 (2nd ed.). Londonderry, Londonderr: INCORE.

Felitti, V. J., Anda, R. F., Nordenberg, D., Williamson, D. F., Spitz, A. M., Edwards, V., ... Marks, J. S. (1998). Relationship of childhood abuse and household dysfunction to many of the leading causes of death in adults. The adverse childhood experiences (ACE) study. American Journal of Preventative Medicine, 14(4), 245-258. doi:10.1016/S0749-3797(98) 00017-8

Filton, L., Rongqin, Y., \& Fazel, S. (2018). Childhood maltreatment and violent outcomes: A systematic review and meta-analysis of prospective studies. Trauma, Violence and Abuse. doi.org/10.1177/1524838018795269

Finkelhor, D., Ormrod, R., Turner, H., \& Hamby, S. L. (2005). The victimization of children and youth: A comprehensive, national survey. Child Maltreatment, 10, 5-25. doi:10.1177/ 1077559504271287 
Finkelhor, D., Turner, H. A., Ormrod, R. K., \& Hamby, S. L. (2009). Violence, crime, and exposure in a national sample of children and youth. Pediatrics, 124, 5. doi:10.1542/ peds.2009-0467

Foa, E. B., \& Rothbaum, B. O. (1998). Treating the trauma of rape: Cognitive behavioural therapy for PTSD. New York, NY: Guilford Press.

Fonaghy, P., Target, M., Gergely, G., Allen, J., \& Bateman, A. (2003). The developmental roots of borderline personality disorder in early attachment relationships: A theory and some evidence. Psychoanalytic Enquiry, 23(3), 412-459. doi:10.1080/07351692309349042

Ford, J. D., \& Courtois, C. A. (2009). Defining and understanding complex trauma and complex trauma disorders. In C. A. Courtois \& J. D. Ford (Eds.), Treating complex traumatic stress disorders: An evidence- based guide (pp. 13-30). New York, NY: Guilford Press.

Gadd, D., \& Jefferson, T. (2007). Psycho-social criminology. London, UK: Sage.

Garland, D. (2002). Of crimes and criminals: The development of criminology in Britain. In M. Maguire, M. Morgan, \& R. Reiner (Eds.), The oxford book of criminology (3rd ed., pp. 750). Oxford, UK: Oxford University Press.

Goodey, J. (1997). Boy's don't cry. British Journal of Criminology, 37(3), 401-418.

Grasso, D., Dierkhishing, C., Branson, C., Ford, J., \& Lee, R. (2015). Developmental patterns of adverse childhood experiences and current symptoms and impairment in youth referred for trauma-specific services. Journal of Abnormal Child Psychology, 44, 871-886. doi:10.1007/s10802-015-0086-8

Greenwald, R. (2002). The role of trauma in conduct disorder. Journal of Aggression Maltreatment \& Trauma, 6(1), 5-23. doi:10.1300/J146v06n01_02

Halbern, C. T., Udry, J. R., Campbell, B., \& Suchindran, C. (1994). Relationships between aggression and pubertal increases in testosterone: A panel analysis of adolescent males. Society of Biology, 40, 8-24.

Hamby, S., Taylor, E., \& Jones, L. (2018). From poly-victimization to poly-strengths: Understanding the web of violence can transform research on youth violence and illuminate the path to prevention and resilience. Journal of Interpersonal Violence, . $\quad 33,5$ doi: $10.1177 / 0886260517744847$

Harland, K., \& McCready, S. (2014). Rough Justice: Considerations on the role of violence, masculinity and the alienation of young men in communities and peace-building in Northern Ireland. Youth Justice, 14(3), 269-283. doi:10.1177/1473225414549696

Harland, K., \& McCready, S. (2015). Boys, young men and violence: Masculinities, education and practice. Belfast, Northern Ireland: Palgrave Macmillan.

Harris, M., \& Rd, F. (2001). Envisioning a trauma-informed service system: A vital paradigm shift. New Directions for Mental Health Services, 2001, 3-22. doi:10.1002/yd.23320018903

Hasley, M. (2018). Child victims as adult offenders: Foregrounding the criminogenic effects of (unresolved) trauma and loss. British Journal of Criminology, 57, 17-36.

Hawkins, D., Herrenkohl, T., Farrington, D., Brewer, D., \& Catalano, R. (2000). Predictors of youth violence. OJJDP. Rockville, MD: Office of Juvenile Justice and Delinquency Prevention.

Home Office. (2018). Serious violence strategy. London: Author. Retrieved from https://assets. publishing.service.gov.uk/government/uploads/system/uploads/attachment_data/file/ 698009/serious-violence-strategy.pdf

Horn, S., Charney, D., \& Feder, A. (2016). Understanding resilience: New approaches for preventing and treating PTSD. Experimental Neurology, 284, 119-132. doi:10.1016/j. expneurol.2016.07.002

Irvine, H., Livingstone, M., \& Flood, M. (2018). The Man Box: A study on being a young man in Australia. Brisbane, Australia: Queensland University of Technology. 
Jackson, V., Brown, K., \& Stephen, J. (2016). The prevalence of childhood victimization experienced outside of the family: Findings from an English prevalence study. Child Abuse and Neglect, 51, 343-357. doi:10.1016/j.chiabu.2015.08.006

Johnson, S. L. (2009). Improving the school environment to reduce school violence: A review of the literature. Journal of School Health, 79, 451-465.

Jolliffe, D., \& Farrington, D. (2004). Empathy and offending: A systematic review and metaanalysis. Aggression and Violent Behavior, 9, 441-476. doi:10.1016/j.avb.2003.03.001 Jones,

D. W. (2012). Psychosocial perspectives: Men, madness and violence. In S. Hall \& S. Winlow (Eds.), New directions in criminological theory (pp. 183-198). Abingdon, England: Routledge.

Kerig, P. K., \& Becker, S. P. (2010). From internalizing to externalizing: Theoretical models of the processes linking PTSD to juvenile delinquency. In S. J. Egan (Ed.), Posttraumatic stress disorder (PTSD): Causes, symptoms and treatment (pp. 33-78). Hauppauge, NY: Nova Science.

Komarovskaya, I. A., Booker-Loper, A., Warren, J., \& Jackson, S. (2011). Exploring gender differences in trauma exposure and the emergence of symptoms of PTSD among incarcerated men and women. The Journal of Forensic Psychiatry \& Psychology, 22(3), 395-410. doi:10.1080/14789949.2011.572989

Krauss, H. (2006). Perspectives on Violence. New York Academy of Sciences, 1087.

Lauterbach, D., \& Armour, C. (2016). Symptom trajectories among child survivors of maltreatment: findings from the Longitudinal Studies of Child Abuse and Neglect (LONGSCAN). Journal of Abnormal Child Psychology, 44(2), 369-379. doi:10.1007/s10802-015-9998-6

Malvaso, C., Delfabro, P., \& Day, A. (2016). Risk factors that influence the maltreatment-offending association: A systematic review of prospective and longitudinal studies. Aggression and Violent Behaviour, 31, 1-15. doi:10.1016/j.avb.2016.06.006

Malvaso, C., Delfabbro, P., \& Day, A. (2018). The maltreatment-offending association: A systematic review of the methodological features of prospective and longitudinal studies. Trauma, Violence \& Abuse, 19, 1.

Malvaso, C., Delfabbro., Day, A., \& Nobes, G. (2018). The maltreatment-violence link: Exploring the role of maltreatment experiences and other individual and social risk factors among young people who offend. Journal of Criminal Justice,555, 3 -45.

Maschi, T., \& Bradley, C. (2008). Exploring the moderating influence of delinquent peers on the link between trauma, anger, and violence among male youth: Implications for social work practice. Child and Adolescent Social Work, 25, 125-138. doi:10.1007/s10560-008-0116-2

Matjasko, J., Vivolo-Kantor., A., Massetti, G., Holland, K., Holt, M., \& Dela Cruz, J. (2012). A systematic meta-review of evaluations of youth violence prevention programs: Common and divergent findings from 25 years of meta-analyses and systematic review. Aggression and Violent Behaviour, 17, 6. doi:10.1016/j.avb.2012.06.006

McAlister, S., Scraton, P., \& Haydon, D. (2014). Childhood in transition: Growing up in 'post conflict Northern Ireland'. Children's Geographies, 12(3), 297-311. doi:10.1080/ 14733285.2014.888399

McNaughton-Ryes, H. L., Foshee, V. A., Chen, M. S., \& Ennett, S. (2018). Patterns of adolescent aggression and victimisation: Sex differences and correlates. Journal of Aggression, Maltreatmetn \& Trauma. doi:10.1080/10926771.2018.1466843

Messerschmidt, J. (1993). Masculinities and crime: Critique and reconceptualization of theory. Lanham, MD: Rowman \& Littlefield.

Messina, N., \& Grella, C. (2006). American Journal Of Public Health, 96, 1842-8. doi:10.2105/ AJPH.2005.082016 
Mikhail, J. N., \& Nemeth, L. S. (2015). Trauma center based youth violence prevention programmes: An integrative review. Trauma, Violence and Abuse, 17(5), 500-519. doi: $10.1177 / 1524838015584373$

Morina, N., Koerssen, R., \& Pollet, T. (2016). Interventions for children and adolescents with posttraumatic stress disorder: A meta-analysis of comparative outcome studies. Clinical Psychology Review, 47, 41-54. doi:10.1016/j.cpr.2016.05.006

Morris, L., Salkovskis, P., Adams, J., Lister, A., \& Meiser-Stedman, R. (2015). Screening for post-traumatic stress symptoms in looked after children. Journal of Children's Services, 10 (4), 365-375. doi:10.1108/JCS-10-2014-0045

NHS Scotland (2017). Transforming psychological trauma: A knowledge and skills framework for the Scottish Workforce. Scottish Government. Retrieved from https://www.nes. scot.nhs.uk/media/3971582/nationaltraumatrainingframework.pdf

NISRA. (2018). Research and Statistical Bulletin 01/2018 'Perceptions of Crime: Findings from the 2016/17 Northern Ireland Crime Survey'. https://www.justice-ni.gov.uk/news/ research-and-statistical-bulletin-012018-perceptions-crime-findings-201617-northernireland-crime

Nöthling, J., Suliman, S., Martin, L., Simmons, C., \& Seedat, S. (2016). Differences in abuse, neglect, and exposure to community violence in adolescents with and without PTSD and depression. Journal of Interpersonal Violence, 1, 27.

ONS. (2018). The nature of violent crime in England \& Wales: Year ending March 2017. London, UK: Author.

Piquero, A. R., Jennings, W. G., \& Barnes, J. C. (2012). Violence in criminal careers: A review of the literature from a developmental life-course perspective. Aggression and Violent Behavior, 17(3), 171-179. doi:10.1016/j.avb.2012.02.008

PSNI. (2018). Police recorded crime in Northern Ireland: Monthly update 31st March 2018. Belfast: Police Service of Northern Ireland. https://www.psni.police.uk/globalassets/insidethe-psni/our-statistics/police-recorded-crime-statistics/2018/march/monthly-crime- bulletinapr-mar-17_18.pdf

Raissian, K. M., Dierkhising, C. B., Geiger, J. M., \& Schelbe, L. (2014). Child maltreatment reporting patterns and predictors of substantiation: Comparing adolescents and younger children. Child Maltreatment, 19, 3-16. doi:10.1177/1077559513518096

Ramon, S. (P889hopathy: its professional and social context in Britain. In Miller, P and Rose, N. (Eds.), The Power of Psychiatry. Cambridge: Polity.

Reardon, C., \& Govender, K. (2013). Masculinities, cultural worldviews and risk perceptions among South African adolescent learners. Journal of Risk Research, 16, 6. doi:10.1080/ 13669877.2012.737823

Richter, L. M., Matthews, S., Kagura, J., \& Nonterah, E. (2018). A longitudinal perspective on violence in the lives of South African children from the birth to twenty plus cohort study in Johannesburg-Soweto. South African Medical Journal, 108(3), 181-186. doi:10.7196/ SAMJ.2018.v108i3.12661

Sundaram, V. (2013). Violence as understandable, deserved or unacceptable? Listening for gender in teenagers' talk about violence. Gender and Education, 25, 7. doi:10.1080/ 09540253.2013.858110

Taylor, I., Walter, P., \& Young, J. (1973). The new criminology (1st ed.). New York, NY: Routledge.

Taylor, I., Walton, P., \& Young, J. (2013). The new criminology (2nd ed.). New York, NY: Routledge.

Tfofi, M., Farrington, D., \& Losel, F. (2012). School bullying as a predictor of violence later in life: A systematic review and meta-analysis of prospective longitudinal studies. Aggression and Violent Behavior, 13, 1-4. 
Trickey, D., Siddaway, A., Meiser-Stedman, R., Serpell, L., \& Field, A. (2010). A meta-analysis of risk factors for post-traumatic stress disorder in children and adolescents. Clinical Psychology Review, 32, 122-138. doi:10.1016/j.cpr.2011.12.001

Turner, R. J., \& Lloyd, D. A. (1995). Lifetime traumas and mental health: The significance of cumulative adversity. Journal of Health and Social Behavior, 36, 360-375. doi:10.2307/2137325

UNICEF. (2017). A familiar face: Violence in the lives of children and adolescents. Retrieved from https://www.unicef.org/publications/index_101397.html

van der Merwe, A., \& Dawes, A. (2009). Youth violence: A review of risk factors, causal pathways and effective intervention. Journal of Child \& Adolescent Mental Health, 19(2), 95-113. doi:10.2989/17280580709486645

van der Put, C. E., Lanctot, N., de Ruiter, C., \& van Vugt, E. (2015). Child maltreatment among boy and girl probationers: Does type of maltreatment make a difference in offend- ing behavior and psychosocial problems? Child Abuse \& Neglect, 46, 142-151.

Vaswani, N. (2018). Adverse Childhood Experiences in children at high risk of harm to others. A gendered perspective. Centre for Youth and Criminal Justice. Glasgow: University of Strathclyde.

Veenstra, L., Bushman, B., \& Koole, S. (2018). The facts on the furious: A brief review of the psychology of trait anger. Current Opinion in Psychology, 19, 98-103. doi:10.1016/j. copsyc.2017.03.014

Walsh, C. (2018, October). Addressing serious male youth violence: Missed opportunities within the UK serious youth violence strategy. Youth and Policy, 2018. http://www. youthandpolicy.org/articles/addressing-serious-male-youth-violence-missed-opportunitieswithin-the-uk-serious-youth-violence-strategy/

Widom, C. S. (1989). The cycle of violence. Science, 244, 160-166. doi:10.1126/ science.244.4910.1244-b

Winstok, Z., \& Weinberg, M. (2018). From posttrauma to gender and back: A gender motivation theory-explanation of gender differences in trauma exposure, symptoms, diag- nosis, and implications. Journal of Aggression, Maltreatment and Trauma, 27(9), 959-982. doi:10.1080/10926771.2017.1420719

Ying, L., Wu, X., \& Lin, C. (2012). Longitudinal linkages between depressive and posttraumatic stress symptoms in adolescent survivors following the Wenchuan earthquake in China: A three-wave, cross-lagged study. School Psychology International, 33, 416-432. doi: $10.1177 / 0143034311421271$ 